\title{
Heterotrophic Utilisation of Particulate Matter from the Kelp Laminaria pallida
}

\author{
V. Stuart ${ }^{1}$, M. I. Lucas ${ }^{2}$ and R. C. Newell ${ }^{2}$ \\ ${ }^{1}$ Department of Zoology, University of Cape Town, Rondebosch 7700, South Africa \\ ${ }^{2}$ Institute for Marine Environmental Research, Prospect Place, Plymouth PL1 3DH, England
}

\begin{abstract}
The microbial community which colonises particulate debris from the kelp Laminaria pallida shows a succession from bacteria, through flagellates, ciliates, amoebae and choanoflagellates over a period of up to $34 \mathrm{~d}$ incubation at $10^{\circ} \mathrm{C}$. The biomass of bacteria reaches only $16.5 \mathrm{mg} \mathrm{g}^{-1}$ of added organic matter compared with $42 \mathrm{mg} \mathrm{g}^{-1}$ dry weight of dissolved organic matter added from kelp mucilage, despite the fact that the combined biomass of grazing protozoans in both cases was $4.2-4.6 \mathrm{mg}$ $\mathrm{g}^{-1}$ of added organic matter. This suggests that the dissolved components of mucilage, comprising principally the acyclic polyol D-mannitol and other carbohydrates, are more readily utilisable as a substrate than the particulate components of kelp debris. The carbon in particulate debris is converted into bacterial biomass with an efficiency of approximately $11 \%$ compared with values of up to $29 \%$ which have been reported for mucilage incubated with seawater during the summer Differences in conversion efficiency of soluble compounds and particulate debris from $L$. pallida are also reflected in the time taken for utilisation by microheterotrophs under culture conditions. The time taken for $50 \%$ utilisation of particulate debris at $10{ }^{\circ} \mathrm{C}$ was $240 \mathrm{~h}$ compared with reported values of $144 \mathrm{~h}$ for sugars and alginates and only $48 \mathrm{~h}$ for mannitol incubated at $10^{\circ} \mathrm{C}$. Estimates of the relative significance of dissolved and particulate components released during fragmentation of kelp suggest that out of an annual average carbon production of $820.5 \times 10^{4} \mathrm{~kg}$ from a kelp bed of $700 \mathrm{ha}$, a dry bacterial biomass of $72.20 \times 10^{4} \mathrm{~kg}$ is supported by particulate production and $29.9 \times 10^{4} \mathrm{~kg}$ from mucilage, yielding a total bacterial biomass of $102.10 \times 10^{4} \mathrm{~kg}$. Because of the rapid turnover time of dissolved components, it is suggested that mucilage production supports mainly the dense population of free-living bacteria which are characteristic of kelp beds whilst the bacteria associated with the more refractory particulate matter may be exported to adjacent communities.
\end{abstract}

\section{INTRODUCTION}

The significance of primary production by marine macrophytes and other plants compared with that of the phytoplankton in coastal waters has been widely recognised (Teal, 1962; Williams and Murdoch, 1969; Wheeler, 1976; Woodwell et al., 1977; for review see Newell, 1979). Mann (1973), for example, estimated that annual primary production in the seaweed zone at St Margaret's Bay, Nova Scotia, Canada, was approximately $603 \mathrm{~g} \mathrm{C} \mathrm{m}^{-2}$ compared with only $191 \mathrm{~g} \mathrm{C} \mathrm{m}^{-2}$ for phytoplankton. Marshall (1970) estimated that macrophytes may contribute as much as $50 \%$ of the organic carbon in shallow waters off the New England coast. Again, although the value varies considerably with depth, the mean annual carbon production obtained by Dieckmann (1978) for Laminaria pallida at Oudekraal, on the west coast of the Cape Peninsula, South Africa, was $562 \mathrm{~g} \mathrm{~m}^{-2}$. Of this, some $34 \%$ of the energy is represented by dissolved organic matter whilst the rest is released as a particulate component into the water column (Newell at al., 1980). This value is comparable with that obtained by Johnston et al. (1977) who estimated that as much as $77 \%$ of the net carbon fixed by $L$. saccharina in Loch Creran, Scotland, appears as particulate matter. Release of particulate matter during fragmentation by L. pallida is thus likely to be approximately $450 \mathrm{~g}$ carbon $\mathrm{m}^{-2} \mathrm{y}^{-1}$ and values of $1.7-2.0 \mathrm{mg}$ ash-free dry weight $\mathrm{l}^{-1}$ are commonly recorded in coastal waters near to the kelp bed at Oudekraal (Field et al., 1980).

We have recently shown that the dissolved component released as mucilage during fragmentation from the tip of the fronds of both Laminaria pallida and Ecklonia maximia is rich in the acyclic polyol D-mannitol which can be utilised by bacteria within $48 \mathrm{~h}$ at $10^{\circ} \mathrm{C}$, and that other carbohydrates are utilised more slowly (Newell et al., 1980; Lucas et al., 1981). The efficiency of conversion of organic carbon in the soluble components of mucilage into bacterial biomass varied from approximately $12 \%$ in winter to as much as $29.4 \%$ in summer. Annual mucilage release during 
fragmentation from a small kelp bed of 700 ha was estimated as approximately $1460 \times 10^{4} \mathrm{~kg}$ dry mass and was thus calculated to be capable of supporting a dry biomass of approximately $30 \times 10^{4} \mathrm{~kg}$ bacteria as well as $3 \times 10^{4} \mathrm{~kg}$ dry biomass of ciliates and flagellates which graze on the bacteria (Linley et al., 1981; Lucas et al., 1981).

The heterotrophic utilisation of the particulate component, comprising the remaining $80 \%$ of primary production by kelp is, however, less well-known although a good deal of work has been carried out on plant debris from other sources. Odum and de la Cruz (1967), for example, studied the initial phases of biodegradation of saltmarsh plants including species of Juncus, Distichlis, Spartina and Salicornia. More recently, studies on the turtle grass Thalassia (Fenchel, 1970, 1972; Knauer and Ayres, 1977) and on the eelgrass Zostera (Harrison and Mann, 1975a, b; Penhale and Smith, 1977) have been combined with direct observations on the microheterotrophic population associated with the degradation of plant debris. Particulate matter from such plants, as well as from algae such as Ascophyllum and Laminaria (Chan and McManus, 1969; Laycock, 1974; Mazure and Field, 1980), have been shown to be capable of supporting a complex microbial population which may utilise the debris as a substrate and subsequently form a potentially important food resource for larger consumer organisms (Newell, 1965, 1979; Fenchel, 1972; Tenore, 1975).

The following work was therefore undertaken to study quantitatively the heterotrophic succession of micro-organisms which colonise the particulate component of kelp debris, so that comparisons can be made between the relative significance of dissolved and particulate components as a substrate for marine microheterotrophs (see also Linley et al., 1981). The rate of loss of particulate matter and the simultaneous increase in biomass of microheterotrophs can then be used to assess the conversion efficiency of particulate matter by the micro-organisms. This allows some estimate to be made of the turnover time of particulate debris compared with the dissolved components, and the microbial biomass which can be supported by the release of particulate matter during fragmentation of kelp.

\section{MATERIAL AND METHODS}

\section{Preparation and Incubation of Detritus}

Fronds from Laminaria pallida were collected from a kelp bed at Oudekraal, on the west coast of the Cape Peninsula, South Africa, and brought in an ice-cold container to the laboratory. They were thoroughly washed to remove epiphytes and the mucilage secreted during transport of the kelp to the laboratory. Eroding tips were removed from the fronds, freezedried and ground in a mill. The powdered detritus was then sieved to obtain particles from 43-63 $\mu \mathrm{m}$ diameter and sterilised in Petri dishes held under ultra-violet light for $24 \mathrm{~h}$. This particle-size range was similar to the dominant fraction found in seawater collected from the vicinity of the kelp bed.

Incubation experiments were carried out in sterilised conical flasks which contained $0.5 \mathrm{~g}$ sterile detritus plus $1.5 \mathrm{l}$ of $53 \mu \mathrm{m}$ filtered seawater freshly collected from the kelp bed. Control flasks containing $0.5 \mathrm{~g}$ sterile detritus plus $0.2 \mu \mathrm{m}$ filtered and autoclaved seawater were incubated with each experimental flask. Both flasks were sealed with rubber stoppers and $0.2 \mu \mathrm{m}$ Nuclepore-filtered air was drawn first through the control flask and then through the experimental flask to minimise contamination. The flasks were incubated at $10^{\circ} \mathrm{C}$ in a shaking water bath to maintain the debris in suspension, and were illuminated with a $12 \mathrm{~h}$ cycle by means of fluorescent tubes. Samples were removed from the flasks via a sterilised tube in the stopper by means of a sterilised syringe on Days $0,1,2$ and on each 4 th day up to Day 30.

\section{Microbial Numbers and Biomass}

Cell numbers were estimated using the acridine orange direct count (AODC) method based on Hobbie et al. (1977), as described by Linley et al. (1981). Cell dimensions were then estimated from scanning electron micrographs of filtered samples of the incubation media (Linley et al., 1981), and biomass calculated from numbers and volumes of the cells together with estimates of their specific gravity obtained from the literature (Calkins and Summers, 1941; Luria, 1960; Doetsch and Cook, 1973; Linley et al., 1981).

\section{Dry Mass of Particulate Matter}

Triplicate samples of $6 \mathrm{ml}$ were withdrawn from experimental and control flasks each sampling day and filtered onto $2.5 \mathrm{~cm}$ diameter glass fibre filters (Whatman GF/C) which had been preashed at $460^{\circ} \mathrm{C}$ for $5 \mathrm{~h}$. The filtrate was rinsed with an isosmotic ammonium formate solution to remove soluble salts and dried in an oven at $70^{\circ} \mathrm{C}$ for $48 \mathrm{~h}$. The filters were then cooled in a desiccator and weighed on an electronic balance accurate to $1.0 \mu \mathrm{g}$ (Mettler ME 30). The ash content of the filtrate was determined by heating 
the filters in a muffle furnace at $470^{\circ} \mathrm{C}$ for $5 \mathrm{~h}$ and reweighing as before.

\section{Particle Numbers and Size}

Triplicate samples of $1.0 \mu 1$ were diluted 1:50 with $0.2 \mu \mathrm{m}$ Nuclepore filtered seawater. The number of particles was counted and the size distribution in Channels 3-16 $(6.35-128.0 \mu \mathrm{m})$ estimated by means of a 16 channel Coulter Counter (Model TA II) equipped with a $280 \mu \mathrm{m}$ aperture orifice tube. The mean number of counts per channel was corrected for background counts in $0.2 \mu \mathrm{m}$ filtered seawater. Particle-size distribution was expressed in parts per million (obtained from the product of the geometric mean volume and particle numbers) plotted against the $\log _{10}$ of mean particle diameter for each channel (Strickland and Parsons, 1972).

\section{Total Carbohydrates Excluding Polyols}

Simple sugars, oligosaccharides, polysaccharides and their derivatives, excluding polyols, were estimated colorimetrically as 'glucose equivalents' from the phenol-sulphuric acid reaction described by Dubois et al. (1956). A sample of $2 \mathrm{ml}$ incubation medium was pipetted into a colorimetric tube followed by $1 \mathrm{ml} 5 \%$ phenol in water. Then $5 \mathrm{ml}$ concentrated sulphuric acid was added rapidly and directed onto the liquid surface to improve mixing. The tubes were allowed to stand for $10 \mathrm{~min}$, shaken and incubated for $15 \mathrm{~min}$ at $25^{\circ}-30^{\circ} \mathrm{C}$. The absorbance of the characteristic yellow-orange colour may then be measured at $490 \mathrm{~m} \mu$ for hexoses and $480 \mathrm{~m} \mu$ for pentoses and uronic acids. In practice, rather different standard curves are obtained for different sugars, so that in the case of total carbohydrate estimations of mixed sugars, it is necessary to prepare standards of the mixed sugars in the proportions which they are likely to occur in mucilage. One of the difficulties in the use of such mixed standards in the analysis of our incubation media is that different components of the carbohydrate pool may be used at different rates whilst the use of a calibration curve of mixed standards is only valid if each component remains in the same relative proportion throughout the experiment. We have therefore expressed total carbohydrate values as 'glucose equivalent' obtained from a series of glucose standards only.

\section{Carbon and Nitrogen Analysis}

Samples of $10 \mathrm{ml}$ of the incubation media were filtered through $3 \mu \mathrm{m}$ Nuclepore membrane filters. The

Table 1. Mean number and volume of micro-organisms present in the incubation medium during a $34 \mathrm{~d}$ period. Mean cell numbers were calculated from AODC counts; volumes were derived from micrometer measurements of S.E.M. scans of the cells

\begin{tabular}{|c|c|c|c|c|c|}
\hline Day & $\begin{array}{l}\text { Bacteria } \\
\left(\times 10^{7}\right)\end{array}$ & $\begin{array}{l}\text { Flagellates } \\
\qquad\left(\times 10^{5}\right)\end{array}$ & $\begin{array}{l}\text { Ciliates } \\
\left(\times 10^{3}\right)\end{array}$ & $\begin{array}{l}\text { Amoebae } \\
\left(\times 10^{3}\right)\end{array}$ & $\begin{array}{c}\text { Choanoflagellates } \\
\qquad\left(\times 10^{3}\right)\end{array}$ \\
\hline \multicolumn{6}{|c|}{ Mean number $\mathrm{ml}^{-1} \pm 1$ S.E. } \\
\hline 0 & $0.07 \pm 0.02$ & & & & \\
\hline 1 & $0.09 \pm 0.01$ & & & & \\
\hline 2 & $0.13 \pm 0.01$ & & & & \\
\hline 6 & $7.19 \pm 0.86$ & & & & \\
\hline 10 & $8.45 \pm 0.32$ & & & & \\
\hline 14 & $4.78 \pm 0.37$ & $8.92 \pm 0.98$ & & & \\
\hline 18 & $1.87 \pm 0.09$ & $6.75 \pm 0.47$ & & & \\
\hline 22 & $1.10 \pm 0.15$ & $3.91 \pm 0.40$ & & & \\
\hline 26 & $1.08 \pm 0.13$ & $0.83 \pm 0.13$ & $0.12 \pm 0.01$ & $0.05 \pm 0.01$ & \\
\hline 30 & $0.50 \pm 0.06$ & $0.31 \pm 0.10$ & $0.47 \pm 0.04$ & $0.18 \pm 0.01$ & \\
\hline 34 & $0.14 \pm 0.02$ & $0.01 \pm 0.02$ & $0.60 \pm 0.07$ & $0.85 \pm 0.06$ & $2.2 \pm 0.15$ \\
\hline \multicolumn{6}{|c|}{ Mean volume $\mu \mathrm{m}^{-3} \pm 1$ S.E. } \\
\hline 0 & $0.64 \pm 0.07$ & & & & \\
\hline 1 & $0.51 \pm 0.14$ & & & & \\
\hline 2 & $0.41 \pm 0.06$ & & & & \\
\hline 6 & $0.21 \pm 0.01$ & & & & \\
\hline 10 & $0.19 \pm 0.01$ & & & & \\
\hline 14 & $0.19 \pm 0.01$ & $5.41 \pm 0.34$ & & & \\
\hline 18 & $0.22 \pm 0.01$ & $4.62 \pm 0.44$ & & & \\
\hline 22 & $0.21 \pm 0.01$ & $3.15 \pm 0.44$ & & & \\
\hline 26 & $0.20 \pm 0.01$ & $3.29 \pm 0.29$ & $286.9 \pm 25.7$ & $109.4 \pm 24.8$ & \\
\hline 30 & $0.16 \pm 0.04$ & $3.54 \pm 0.57$ & $(, \pm \ldots)$ & $(\ldots \pm \ldots)$ & \\
\hline 34 & $0.22 \pm 0.02$ & $4.13 \pm 0.79$ & $(, \pm \ldots)$ & $(" 1 \pm 1)$ & $66.1 \pm 8.6$ \\
\hline
\end{tabular}




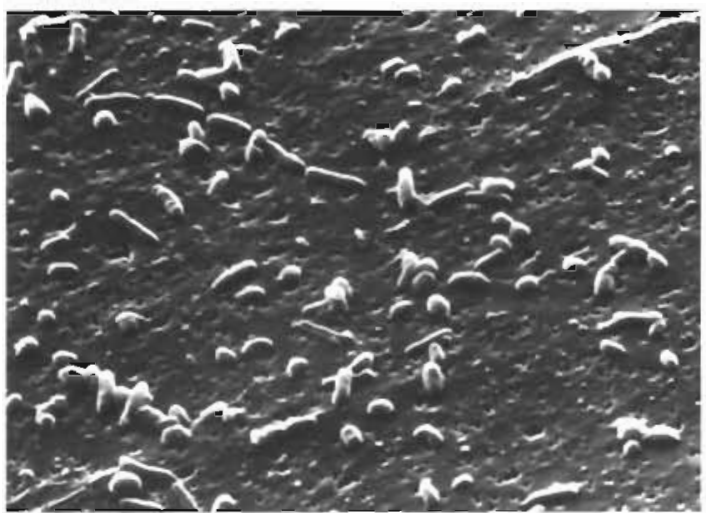

a $-3 \mu \mathrm{m}$

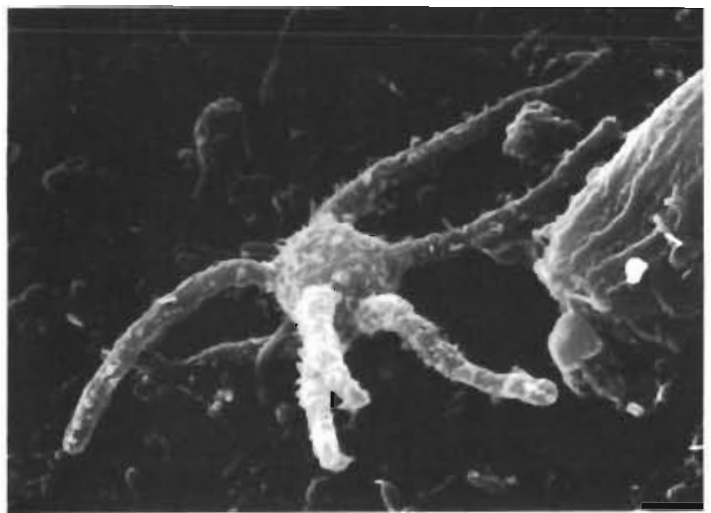

C

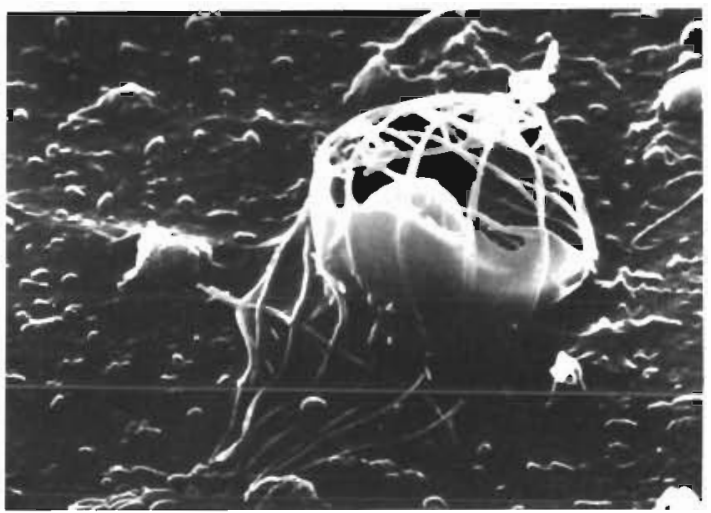

$\mathbf{e}$

$3 \mu \mathrm{m}$

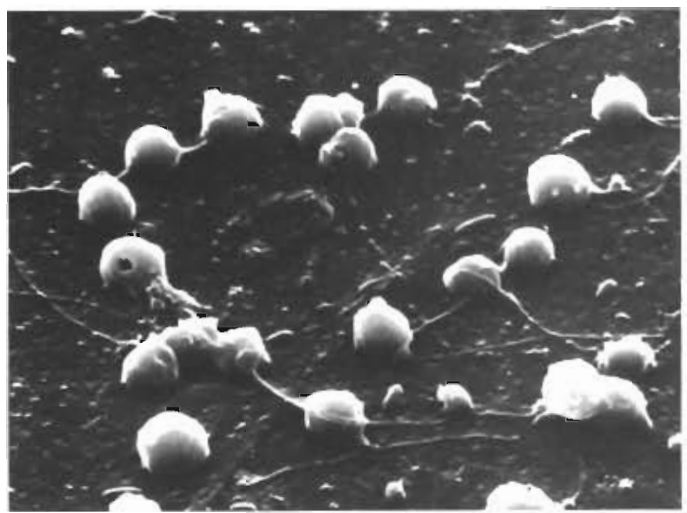

b $\quad-3 \mu \mathrm{m}$
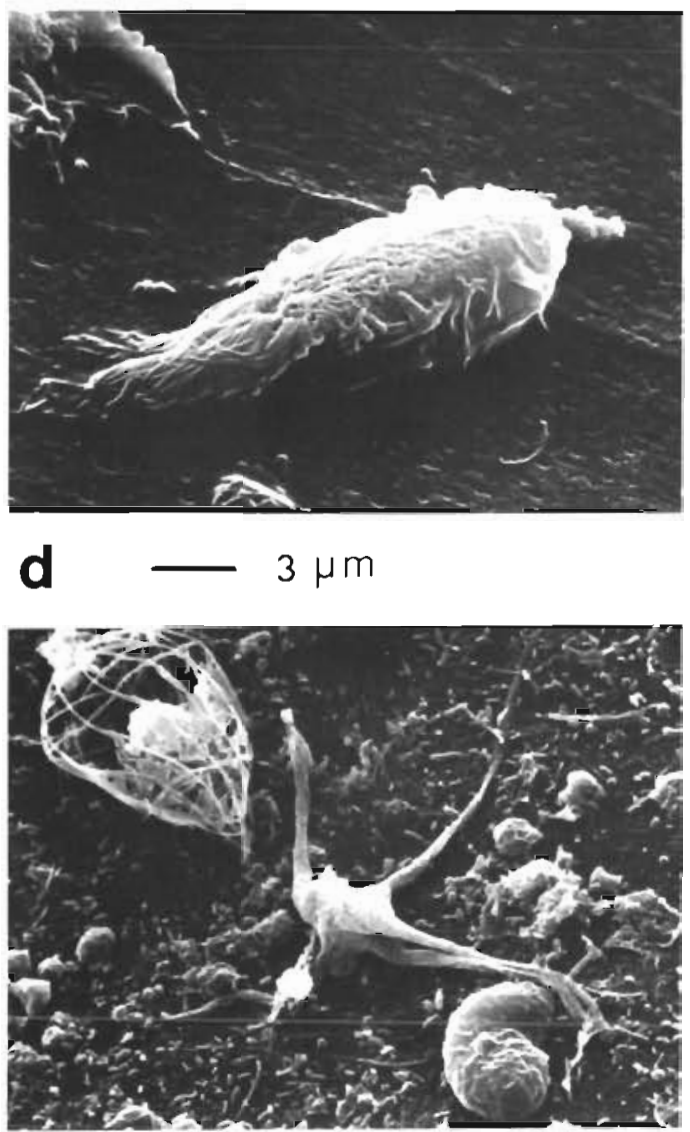

f $-3 \mu \mathrm{m}$

Fig. 1. Selection of micro-organisms developed in the presence of degrading particulate debris from Laminaria pallida. (a) Mixed population of bacterial rods and cocci; (b) phagotrophic flagellates together with phototrophic forms similar to Micromonas. sp.; (c) unidentifiable floating ameoboid form; (d) cyrtophorine ciliate (compare Plate 24-5 in 'Sea Microbes' and Protistologia, 1968, 4: 187-94); it can form a major part of the ciliate microfauna in bacterial films on fouling surfaces; (e) choanoflagellate of the family Acanthoecidae (p. 377 in 'Sea Microbes'), possibly Stephanoeca sp.; (f) choanoflagellate, together with unidentifiable amoeboid form 
filtrate was freeze-dried and a sample of $40 \mathrm{mg}$ of this material used to estimate the carbon and nitrogen in the 'dissolved' fraction. The particulate material retained on the filter was backwashed with $10 \mathrm{ml}$ distilled water, freeze-dried and $20 \mathrm{mg}$ samples used for analysis of the particulate fraction.

Freeze-dried samples were weighed with a Cahn electrobalance and the carbon and nitrogen content measured with a Hewlett-Packard Model 185 B CHN analyser using acetanalide standards $(70.09 \% \quad C$; $10.36 \% \mathrm{~N})$, much as described for mucilage samples (Lucas et al., 1981).

\section{RESULTS}

\section{Microbial Communities Associated with Particulate Debris}

Linley et al. (1981) have described the succession of micro-organisms which colonise incubation media containing $7.21^{-1}$ dried mucilage $\left(=2.18 \mathrm{~g} \mathrm{l}^{-1}\right.$ organic matter) from Laminaria pallida. They showed that the media were first dominated by bacteria which were then replaced by phagotrophic flagellates and ciliates whose numbers controlled the bacterial biomass attained in the incubation media.

Numbers and cell volumes of micro-organisms which colonised incubation media containing $0.33 \mathrm{~g}$ $1^{-1}$ dried particulate debris $\left(=0.254 \mathrm{~g} \mathrm{l}^{-1}\right.$ organic

Table 2. Biomass (mg dry mass 1 $^{-1}$ ) estimated from AODC of the numbers and S.E.M. measurements of the dimensions of micro-organisms in media containing $0.33 \mathrm{~g} \mathrm{~J}^{-1}$ powdered frond of Laminaria pallida incubated at $10^{\circ} \mathrm{C}$ for up to $34 \mathrm{~d}$ in seawater Density of bacteria was taken as 1.07 (Doetsch and Cook, 1973). The following cell densities were used from Calkins and Summers (1941): flagellates 1.042, ciliates 1.039, amoebae 1.043 and choanoflagellates 1.042. A wet to drymass conversion factor of 0.23 was used for bacteria (Luria, 1960), 0.2 for flagellates, ciliates and choanoflagellates, and 0.1 for amoebae (A. J. Lastovica, pers. comm.)

\begin{tabular}{|c|c|c|c|c|c|c|}
\hline Day & Bacteria & $\begin{array}{c}\text { Flagel- } \\
\text { lates }\end{array}$ & Ciliates & $\begin{array}{c}\text { Amoe- } \\
\text { bae }\end{array}$ & $\begin{array}{c}\text { Cho- } \\
\text { ano- } \\
\text { flagel- } \\
\text { lates }\end{array}$ & $\begin{array}{l}\text { Total } \\
\text { micro- } \\
\text { hetero- } \\
\text { trophs }\end{array}$ \\
\hline 0 & 0.117 & - & - & - & $=$ & 0.117 \\
\hline 1 & 0.119 & - & - & - & - & 0.119 \\
\hline 2 & 0.135 & - & - & - & - & 0.135 \\
\hline 6 & 3.804 & - & - & - & - & 3.804 \\
\hline 10 & 4.171 & - & - & - & - & 4.171 \\
\hline 14 & 2.312 & 1.006 & - & - & - & 3.318 \\
\hline 18 & 1.051 & 0.761 & - & - & - & 1.812 \\
\hline 22 & 0.588 & 0.441 & - & - & -- & 1.029 \\
\hline 26 & 0.461 & 0.094 & 0.007 & 0.0005 & - & 0.561 \\
\hline 30 & 0.202 & 0.035 & 0.028 & 0.002 & - & 0.267 \\
\hline 34 & 0.059 & 0.001 & 0.036 & 0.010 & 0.030 & 0.136 \\
\hline
\end{tabular}

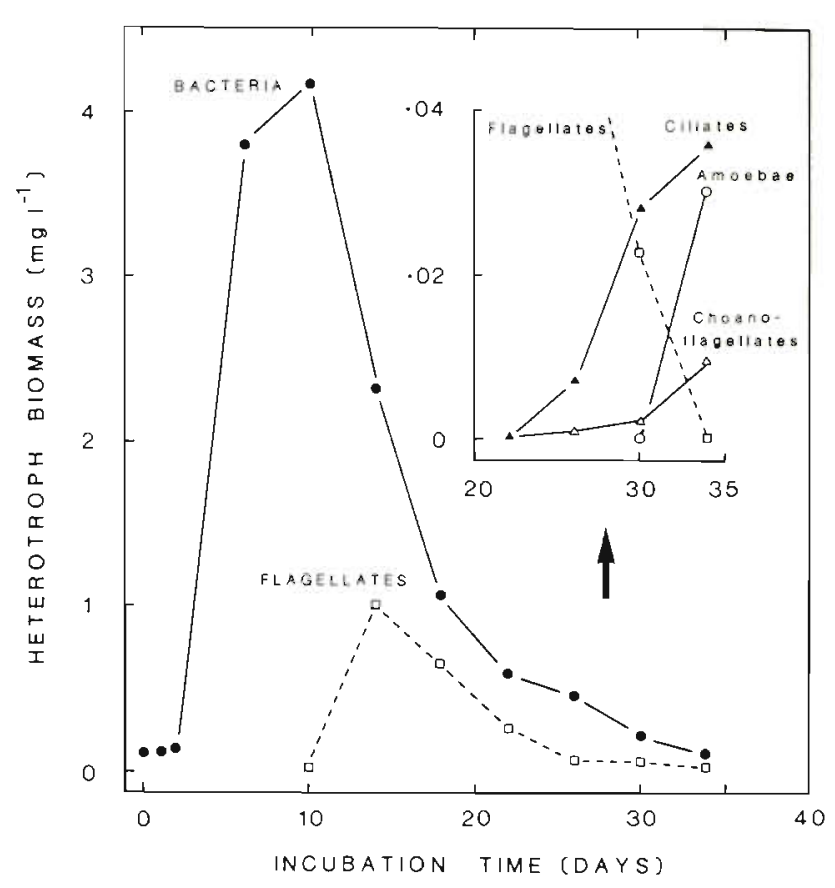

Fig. 2. Biomass of micro-organisms in media containing $0.33 \mathrm{~g}$ $1^{-1}$ dried powdered frond from Laminaria pallida in seawater incubated at $10^{\circ} \mathrm{C}$ for up to $34 \mathrm{~d}$

matter) are shown in Table 1 ; a selection of representative components of the microbial community are illustrated in Figure 1. The most obvious feature of the incubation experiments with particulate debris was that both amoebae and choanoflagellates appeared in the media, whereas in incubation experiments with mucilage alone, the succession comprised only bacteria, flagellates and ciliates. The principal choanoflagellate species was similar to Stephanoeca diplocostata although in some experiments other choanoflagellate species dominated the community towards the end of the incubation period.

Detailed comparisons between the results of Linley et al. (1981) on microbial communities associated with kelp mucilage and those for the particulate component of kelp debris are, however, complicated both by differences in the initial concentration of organic matter in the incubation media and in the cell dimensions of the components of the microheterotrophic succession. It is therefore necessary to express the microbial components in terms of biomass per unit organic matter added at the beginning of the incubation experiment.

\section{Biomass of Micro-Organisms Associated with Particulate Debris}

The biomass of bacteria, flagellates, ciliates, amoebae and choanoflagellates in the media as a function of incubation time at $10^{\circ} \mathrm{C}$ is shown in Table 2 and 
Table 3. Time of appearance of maximal biomass ( $\mathrm{mg} \mathrm{l}^{-1}$ ) of components of the microbial succession which develops in media containing $7.2 \mathrm{~g} \mathrm{l}^{-1}$ dried mucilage from Laminaria pallida ( $\equiv 2.18 \mathrm{~g}$ organic matter $\mathrm{l}^{-1}$ ) and in media containing $0.33 \mathrm{~g} \mathrm{l}^{-1}$ dried particulate matter ( $\equiv 0.254 \mathrm{~g}$ organic matter $1^{-1}$ ) incubated at $10^{\circ} \mathrm{C}$ in seawater collected during summer. Data for mucilage based on Linley et al. (1980). Biomass per g organic matter added to incubation media is also shown

\begin{tabular}{|c|c|c|c|c|c|c|}
\hline \multirow[t]{2}{*}{ Micro-organismus } & \multicolumn{3}{|c|}{$\begin{array}{c}\text { Mucilage } \\
\left(2.18 \mathrm{~g} \text { organic matter } \mathrm{l}^{-1}\right)\end{array}$} & \multicolumn{3}{|c|}{$\begin{array}{c}\text { Particulate debris } \\
\left(0.254 \mathrm{~g} \text { organic matter } \mathrm{I}^{-1}\right)\end{array}$} \\
\hline & Days & $\begin{array}{l}\text { Biomass } \\
\left(\mathrm{mg} \mathrm{l}^{-1}\right)\end{array}$ & $\begin{array}{l}\text { Biomass (mg g }{ }^{-1} \\
\text { organic matter) }\end{array}$ & Days & $\begin{array}{l}\text { Biomass } \\
\left(\mathrm{mg} \mathrm{l^{-1 }}\right)\end{array}$ & $\begin{array}{l}\text { Biomass ( } \mathrm{mg} \mathrm{g} \mathrm{g}^{-1} \\
\text { organic matter) }\end{array}$ \\
\hline Bacteria & 9 & 92.09 & 42.24 & 10 & 4.20 & 16.54 \\
\hline Flagellates & 14 & 2.4 & 1.10 & 14 & 1.00 & 3.9 \\
\hline Ciliates & 14 & 7.56 & 3.47 & 34 & 0.035 & 0.137 \\
\hline Amoebae & - & - & - & 34 & 0.010 & 0.04 \\
\hline Choanoflagellates & - & - & - & 34 & 0.030 & 0.12 \\
\hline
\end{tabular}

Figure 2. The elements of succession from bacteria through flagellates to ciliates noted by Linley et al. (1981) for media containing mucilage from Laminaria pallida is obvious. The major differences in biomass between media containing mucilage and those containing particulate matter are attributable to two main factors. First, as established by Linley et al. (1981), the absolute biomass attained by the bacteria is dependent not only on substrate availability but, above all, on the time of appearance and biomass of grazing phagotrophic flagellates and ciliates. Second, the substrate initially available to the bacteria was as much as $2.18 \mathrm{~g}$ organic matter $1^{-1}$ in the mucilage experiments of Linley et al. (1981) but only $0.254 \mathrm{~g} \mathrm{l}^{-1}$ in the incubation experiments with particulate debris described here.

Table 3 shows the time of appearance and maximal biomass formed by the different components of the microbial succession in experiments with mucilage incubated with seawater collected from the kelp bed in the summer (Linley et al., 1981) and data from Figure 2 for biomass attained in the presence of particulate debris incubated in seawater collected at the same time of the year. The biomass data are also expressed per unit organic matter added at the start of the incubation experiment.

The biomass of bacteria reached $42.24 \mathrm{mg} \mathrm{g}^{-1}$ of added organic matter in mucilage on Day 9 whilst the combined ciliate and flagellate population attained 4.6 $\mathrm{mg}^{-1}$ of added organic matter. In the incubation media containing particulate debris, however, a maximal bacterial population of only $16.54 \mathrm{mg} \mathrm{g}^{-1}$ of added organic matter was attained on Day 10, despite the fact that the combined protozoan community reached 4.2 $\mathrm{mg} \mathrm{g}^{-1}$ of added organic matter. This suggests that the organic matter in the particulate component of kelp debris is less effective as a bacterial substrate than the mannitol and other carbohydrates which characterise the dissolved component. It is, however, necessary to estimate the losses of particulate debris associated with a synchronous increase in microbial biomass in order to calculate the conversion efficiency of the initial steps of the decomposer food chain based on particulate debris.

\section{Losses of Particulate Matter from the Incubation Media}

Incubation of particulate debris for up to $34 \mathrm{~d}$ at $10^{\circ} \mathrm{C}$ in seawater collected from the kelp bed during sum-
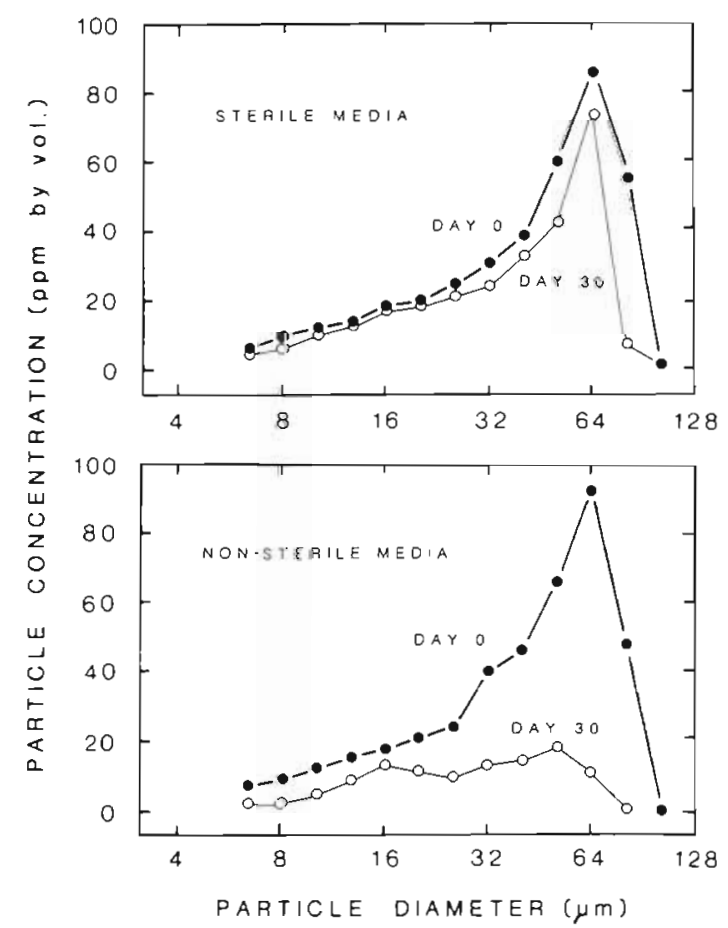

Fig. 3. Laminaria pallida. Particle size distribution of powdered fronds incubated in seawater at $10^{\circ} \mathrm{C}$. Curves at beginning of experiment (solid line) and after $30 \mathrm{~d}$ of incubation at $10^{\circ} \mathrm{C}$. Upper curves are for media initially sterilised under an ultra-violet lamp for $24 \mathrm{~h}$ and made up in autoclaved seawater. Lower curves are for kelp debris in non-sterilised seawater 
Table 4. Loss in dry weight and in organic matter from particulate components of detritus obtained from Laminaria pallida incubated at $10^{\circ} \mathrm{C}$ in seawater Control samples were initially sterilized for $24 \mathrm{~h}$ under an ultra violet lamp and made up in autoclaved seawater, but from Day 14 onwards were contaminated with micro-organisms. The organic component was estimated by ashing the dried filtered samples at $470^{\circ} \mathrm{C}$ for $5 \mathrm{~h}$

\begin{tabular}{|c|c|c|c|c|}
\hline \multirow{2}{*}{ Day } & \multicolumn{2}{|c|}{ Sterile } & \multicolumn{2}{|c|}{ Non-Sterile } \\
\hline & $\begin{array}{c}\text { Total dry mass } \\
\left(\mathrm{mg} \mathrm{l}^{-1}\right)\end{array}$ & $\begin{array}{l}\text { Dry mass of organic matter } \\
\qquad\left(\mathrm{mg} \mathrm{l}^{-1}\right)\end{array}$ & $\begin{array}{c}\text { Total dry mass } \\
\left(\mathrm{mg} \mathrm{l}^{-1}\right)\end{array}$ & $\begin{array}{l}\text { Dry mass of organic matter } \\
\qquad\left(\mathrm{mg} \mathrm{l}^{-1}\right)\end{array}$ \\
\hline 0 & $189.58 \pm 1.25$ & 146.09 & $213.16 \pm 7.52$ & 168.35 \\
\hline 1 & $210.17 \pm 5.53$ & 165.48 & $208.89 \pm 5.07$ & 161.56 \\
\hline 2 & $197.78 \pm 7.39$ & 161.50 & $201.72 \pm 2.14$ & 165.41 \\
\hline 6 & $191.39 \pm 13.12$ & 144.93 & $162.00 \pm 6.83$ & 128.19 \\
\hline 10 & $190.92 \pm 7.19$ & 143.18 & $133.72 \pm 12.16$ & 86.01 \\
\hline 14 & $190.45 \pm 7.56$ & 162.78 & $105.44 \pm 4.51$ & 52.38 \\
\hline 18 & $174.33 \pm 9.38$ & 141.44 & $46.92 \pm 0.46$ & 23.84 \\
\hline 22 & $172.83 \pm 6.66$ & 135.23 & $40.83 \pm 1.83$ & 15.74 \\
\hline 26 & $153.16 \pm 4.16$ & 118.90 & $20.58 \pm 5.24$ & 9.28 \\
\hline 30 & $128.17 \pm 1.36$ & 103.63 & $23.16 \pm 2.33$ & 12.93 \\
\hline
\end{tabular}

mer resulted in a marked loss of particles, especially in the $64 \mu \mathrm{m}$ range. Figure 3 shows the concentration of particles (parts per million, obtained from the product of particle number and geometric mean volume; see Strickland and Parsons, 1972) plotted as a function of particle diameter in sterile and non-sterile seawater on Day zero and after $30 \mathrm{~d}$ incubation at $10^{\circ} \mathrm{C}$. It is evident that some loss of particulate matter occurred even in media which had been initially sterilised, but that such losses were small compared with those in the nonsterilised seawater.

The gross gravimetric losses of particulate material are summarised for the sterile and non-sterile incubation media in Table 4. It is apparent that the development of a microbial community in the media is associated with a gravimetric loss over a period of $30 \mathrm{~d}$ at $10^{\circ} \mathrm{C}$ of as much as $89 \%$ of the powdered debris which was initially added.

The ashed values corresponding to the gravimetric

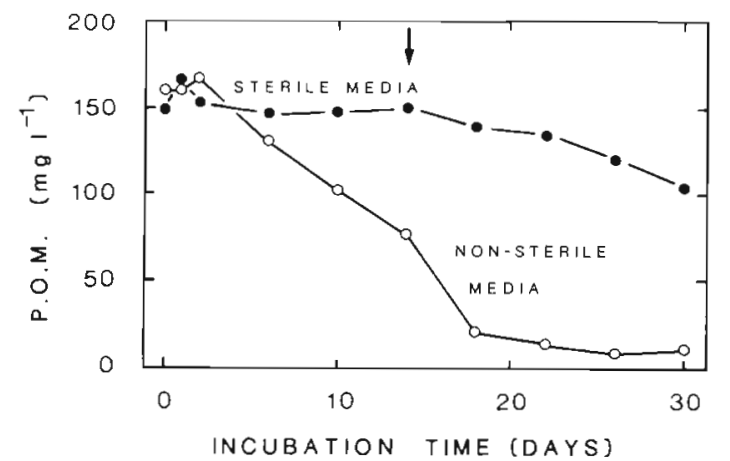

Fig. 4. Concentration of organic matter in the particulate fraction of detritus obtained from Laminaria pallida incubated in seawater for up to $30 \mathrm{~d}$ at $10^{\circ} \mathrm{C}$. The sterile control (closed dots) was prepared by initial sterilisation of the detritus under an ultra-violet light for $24 \mathrm{~h}$, made up in autoclaved seawater. Arrow: time when contamination of control vessels with bacteria was noted losses summarised in Table 4 may be used to calculate the utilisation of organic matter from the incubation media. These values are also shown in Table 4 and are illustrated in Figure 4 which shows that some loss of particulate organic matter occurred in the sterilised media following contamination with micro-organisms from Day 14 onwards. Nevertheless there was a major and sustained utilisation of organic matter from the particulate fraction from Day 2 onwards up to Day 18 in the non-sterilised incubation media.

\section{Losses of Carbohydrates from the Incubation Media}

Because the observed losses of organic matter from the particulate fraction could be accounted for merely by transfer into a dissolved phase, rather than by heterotrophic utilisation of the micro-organisms, it was necessary to measure organic losses from both particulate and dissolved components during the course of the incubation experiments.

Substrate levels for the mixed carbohydrates comprising the particulate and dissolved fractions were estimated by the method of Dubois et al. (1956) and expressed in terms of 'glucose equivalents' (see p. 339, and Lucas et al., 1981). The results are summarised in Table 5 which shows the carbohydrate concentrations

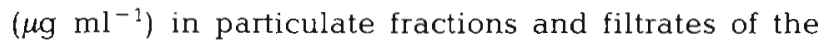
incubation media over a period of $30 \mathrm{~d}$ at $10^{\circ} \mathrm{C}$. It is apparent that some losses of the particulate fraction occurred in the sterilised control samples, especially after Day 14 when some contamination with microorganisms occurred. In this respect the results confirm those obtained with gravimetric methods. At the same time, there was an increase in carbohydrate levels in the filtrate, indicating an initial leaching of soluble carbohydrates (probably mainly mannitol) from the powdered material. 
Table 5. Carbohydrates (expressed as glucose equivalents, $\mu \mathrm{g} \mathrm{m}^{-1}$ ) in media containing an initial concentration of $0.33 \mathrm{~g} \mathrm{l}^{-1}$ dried powdered debris from Laminaria pallida incubated in seawater for up to $30 \mathrm{~d}$ at $10^{\circ} \mathrm{C}$. Values for the particulate and dissolved fraction are shown in both sterile and non-sterile media. Sterilised media were contaminated with bacteria from Day 14 onwards

\begin{tabular}{|c|c|c|c|c|c|c|}
\hline Day & Filtrate & $\begin{array}{l}\text { Sterile } \\
\text { detritus }\end{array}$ & Total & Filtrate & $\begin{array}{c}\text { Non-sterile } \\
\text { detritus }\end{array}$ & Total \\
\hline 0 & 18.64 & 75.74 & 94.38 & 16.08 & 68.92 & 85.00 \\
\hline 1 & 29.97 & 76.09 & 106.06 & 20.09 & 66.99 & 87.08 \\
\hline 2 & 27.88 & 90.39 & 118.27 & 21.43 & 70.17 & 91.60 \\
\hline 6 & 29.10 & 85.27 & 114.37 & 21.08 & 63.11 & 84.14 \\
\hline 10 & 29.62 & 75.51 & 105.13 & 21.49 & 53.78 & 75.27 \\
\hline 14 & 32.82 & 67.38 & 100.20 & 12.94 & 39.25 & 52.19 \\
\hline 18 & 34.39 & 61.10 & 95.49 & 11.84 & 21.24 & 33.08 \\
\hline 22 & 36.01 & 58.31 & 94.32 & 12.01 & 5.62 & 17.63 \\
\hline 26 & 36.88 & 45.76 & 82.64 & 10.21 & 5.16 & 15.37 \\
\hline
\end{tabular}

The particulate matter in the unsterilised incubation media, however, declined from an initial glucose equivalent of $68.92 \mu \mathrm{g} \mathrm{mi}^{-1}$ to only 5.16 on Day 30 and this was accompanied by a decrease in carbohydrate in the filtrate from approximately $21.4 \mu \mathrm{g} \mathrm{ml} \mathrm{m}^{-1}$ to $10.2 \mu \mathrm{g}$ $\mathrm{ml}^{-1}$ on Day 30 . That is, the large utilisation of particulate matter from the experimental media noted in Figure 4 represents a heterotrophic loss rather than merely a conversion into dissolved organic matter. The difference between the organic losses for the sterilised and non-sterilised media can thus be used to calculate the conversion efficiency of particulate organic matter through the first step in the decomposer food chain independently from direct measurements of carbon utilisation.

\section{Carbon Utilisation from the Incubation Media}

The conversion of organic carbon into microbial biomass can most easily be estimated by comparison of the increase in biomass of bacteria with the synchronous loss of organic carbon obtained by direct CHNanalysis of the incubation media (see also Lucas et al., 1981). The results are summarised in Table 6 which shows the values for the biomass of bacteria and those for carbon in both particulate and soluble fractions of the incubation media. The net utilisation of carbon, representing the difference between non-sterile and sterilised control vessels is also shown, as well as the total net utilisation of carbon from both dissolved and particulate phases. It is obvious that some estimate of the overall conversion of organ c carbon into bacterial biomass can be obtained from the increase in bacterial biomass and total carbon utilised up to Day 14 when protozoans appeared. This gives a value for the overall conversion of some $13.5 \%$, the majority of the carbon being utilised from the particulate fraction.

Such overall estimates from carbon production are, however, somewhat misleading since it can be seen from Table 6 that for the first $2 \mathrm{~d}$ a trivial increase in bacterial biomass of only $0.018 \mu \mathrm{g} \mathrm{ml}^{-1}$ was accompanied by a major utilisation of organic carbon of $21.24 \mu \mathrm{g} \mathrm{ml}^{-1}$ yielding a biomass: carbon conversion efficiency of only $0.085 \%$. From Days $2-6$ the bacterial biomass increased dramatically by $3.699 \mu \mathrm{g} \mathrm{ml^{-1 }}$ and was accompanied by a loss of organic carbon of only $5.56 \mu \mathrm{g} \mathrm{ml} \mathrm{m}^{-1}$ which yields an apparent conversion efficiency of $65.99 \%$. After this, between Days 6 and 10 there was a slower increase in bacterial biomass of

Table 6 . Biomass of bacteria $\left(\mu \mathrm{g} \mathrm{ml}^{-1}\right)$ and simultaneous utilisation of carbon $\left(\mu \mathrm{g} \mathrm{ml}^{-1}\right)$ from dissolved and particulate fractions in sterile and unsterile incubation media containing $0.33 \mathrm{~g} \mathrm{l}^{-1}\left(\equiv 0.254 \mathrm{~g} \mathrm{l}^{-1}\right)$ dried powdered frond from Laminaria pallida. Media made up in seawater collected during summer and incubated at $10^{\circ} \mathrm{C}$. Net loss obtained by subtraction of non-sterilised from sterilised media; $\cdot$ denotes interpolated value

\begin{tabular}{|c|c|c|c|c|c|c|c|c|}
\hline \multirow[t]{2}{*}{ Day } & \multirow{2}{*}{ 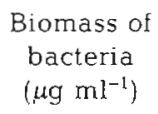 } & \multicolumn{3}{|c|}{ Dissolved fraction $\left.(\mu \mathrm{g} \mathrm{m})^{-1}\right)$} & \multicolumn{3}{|c|}{ Particulate fraction $\left(\mu \mathrm{g} \mathrm{ml}^{-1}\right)$} & \multirow{2}{*}{$\begin{array}{c}\text { Total carbon } \\
\text { utilised } \\
\left(\mu \mathrm{g} \mathrm{ml} l^{-1}\right)\end{array}$} \\
\hline & & Sterile & $\begin{array}{l}\text { Un- } \\
\text { sterile }\end{array}$ & $\begin{array}{l}\text { Net } \\
\text { utilisation }\end{array}$ & Sterile & $\begin{array}{l}\text { Un- } \\
\text { sterile }\end{array}$ & $\begin{array}{l}\text { Net } \\
\text { utilisation }\end{array}$ & \\
\hline 0 & 0.117 & 46.39 & 54.99 & 0 & 80.33 & 78.48 & 1.85 & 1.85 \\
\hline 1 & 0.119 & 61.16 & 53.86 & 7.3 & 81.26 & 71.40 & 9.86 & 17.16 \\
\hline 2 & 0.135 & 48.28 & 40.69 & 7.59 & 81.28 & 65.78 & 15.50 & 23.09 \\
\hline 6 & 3.804 & 48.74 & 42.78 & 5.96 & 78.04 & 55.35 & 22.69 & 28.65 \\
\hline 10 & 4.171 & 45.96 & 42.93 & 3.03 & 78.04 & 55.67 & 22.37 & $32.0^{\circ}$ \\
\hline 14 & 3.318 & 47.23 & 42.43 & 4.8 & 81.04 & 51.40 & 29.50 & 34.30 \\
\hline
\end{tabular}




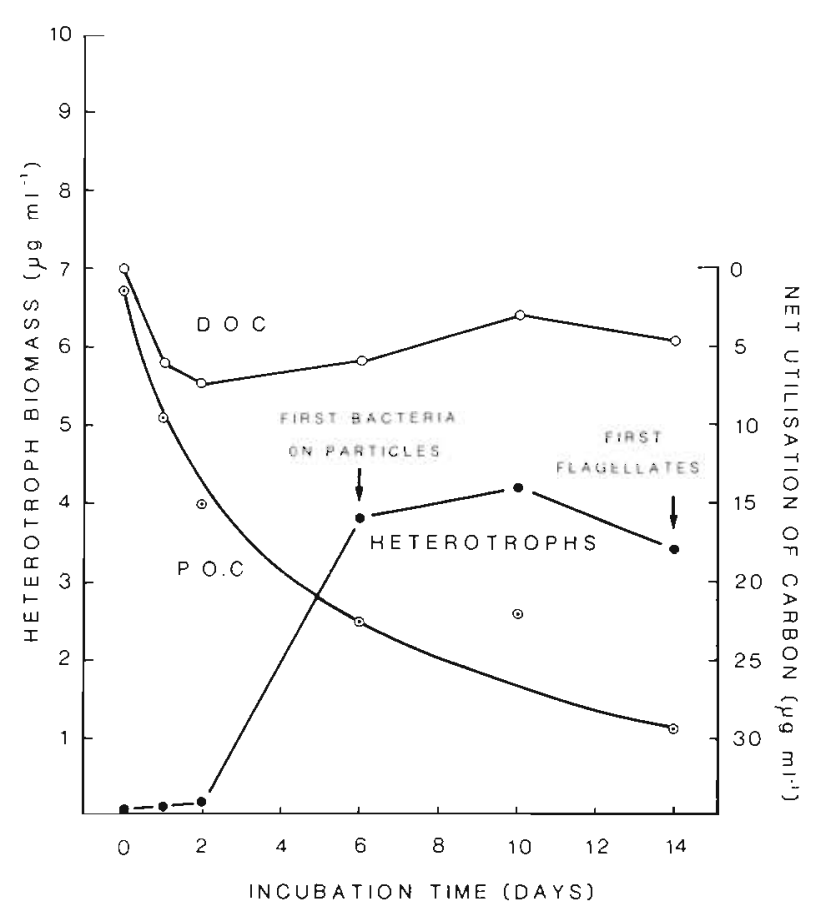

Fig. 5. Increase in biomass of microheterotrophs $\left(\mu \mathrm{g} \mathrm{ml}^{-1}\right)$ and simultaneous net utilisation of organic carbon from dissolved and particulate fractions of powdered fresh Laminaria pallida frond incubated at $10^{\circ} \mathrm{C}$ for up to $30 \mathrm{~d}$. Independent assays of gravimetric loss suggest that particulate fraction is utilised uniformly up to Day 14 (see also Table 4). The carbon utilisation curve was therefore drawn on the assumption that the point for Day 10 is erroneously high

$0.367 \mu \mathrm{g} \mathrm{ml}^{-1}$ carbon, giving a conversion efficiency of approximately $11 \%$.

The values for the biomass of microheterotrophs and the corresponding net utilisation of carbon from the dissolved and particulate fractions are shown in Figure 5 which shows several features of interest in an interpretation of the heterotrophic fate of freshly powdered kelp debris. It will be seen that during the first $2 \mathrm{~d}$ of incubation there was a utilisation of carbon from the dissolved fraction and also some loss of carbon from the particulate material, probably by leaching, whilst the bacterial biomass showed little sign of increase. After this, from Days 2-6 the bacteria evidently entered a growth phase and were apparently capable of a conversion efficiency of substrate carbon into bacterial biomass of approximately $66 \%$. This is equivalent to a carbon:carbon conversion efficiency of about $33 \%$ since bacteria contain some $50 \%$ carbon per unit dry mass. Between Days 6-10 utilisation of carbon was from the particulate material only and was accompanied by a marked decline in the rate of bacterial increase, despite the fact that grazing flagellates were absent until Day 14. The conversion efficiency of the particulate carbon to bacterial biomass during this phase fell to approximately 10-11\%.
The variations in apparent conversion efficiency during the course of incubation can also be estimated from the gravimetric losses of particulate material summarised in Table 4 which shows a loss of $46 \mathrm{mg} \mathrm{l}^{-1}$ from Days 2-6 and a further loss of $28.28 \mathrm{mg} \mathrm{l}^{-1}$ from Days 6-10. The carbohydrate content of the sterilised detritus was approximately $40 \%$ of the dry mass of the particulate debris (Newell and Lucas, in press) and $40 \%$ of the carbohydrates will represent to carbon content of the debris. The carbon losses are thus $7.36 \mathrm{mg} \mathrm{l}^{-1}$ from Days 2-6 and $4.52 \mathrm{mg} \mathrm{l}^{-1}$ from Days $6-10$. This yields an initial conversion efficiency of particulate carbon into bacterial biomass of $3.67 / 7.36$ $\times 100=49.9 \%$ falling to $0.37 / 4.52 \times 100=8.18 \%$.

\section{CONCLUSION}

The results presented show that the biomass of bacteria which colonise particulate organic matter incubated at $10^{\circ} \mathrm{C}$ in seawater collected during the summer reaches only $16.5 \mathrm{mg} \mathrm{g}^{-1}$ of added organic matter compared with $42 \mathrm{mg} \mathrm{g}^{-1}$ dry mass of dissolved organic matter added from kelp mucilage (Lucas et al., 1981), despite the fact that the combined biomass of grazing ciliates and flagellates in both cases was $4.2-4.6 \mathrm{mg} \mathrm{g}^{-1}$ of added organic matter. This suggests that the dissolved components of mucilage, comprising principally the acyclic polyol D-mannitol and other soluble carbohydrates, are more readily utilisable as a substrate than the less soluble components such as alginates which comprise as much as $45 \%$ of the dry mass of powdered kelp debris (Newell and Lucas, in press).

It is likely that the initial value of as much as $66 \%$ for the conversion efficiency of carbon from freshly powdered kelp frond into bacterial biomass reflects the utilisation of dissolved leachates from the material and during this time the bacteria were noted to be principally free-living forms, rather than ones which were attached to particulate matter. Such leachates are known to comprise principally mannitol and other soluble carbohydrates which are capable of rapid heterotrophic utilisation by bacteria within $48 \mathrm{~h}$ under culture conditions at $10^{\circ} \mathrm{C}$ (Newell et al., 1980; Lucas et al., 1981). An initial increase in dissolved carbohydrates in filtrates of the sterilised incubation media is shown in Table 5 (see also p. 344) and mannitol was identified by paper chromatography as one of the components which disappeared from the leachate within $24 \mathrm{~h}$ of the appearance of bacteria (i. e., by Day 3) in non-sterilised media. This initial value for the carbon conversion efficiency is considerably higher than the overall value of $29 \%$ obtained by Lucas et al., 1981) for dissolved components of mucilage incubated in seawater at this 
time of the year (summer) although they also noted that conversion values could reach $68 \%$ during the logistic growth phase of the bacteria.

Thus once the bacteria have colonised particulate debris and have entered a rapid growth phase, there may be a high conversion efficiency of carbon into bacterial biomass during which time soluble components associated with the debris are utilised. The nitrogen in the particulate debris was equivalent to a protein content of about $26 \%$ of the total dry weight (Newell and Lucas, in press) so that the debris represents a nitrogen-rich substrate compared with mucilage. We have found that bacteria do not grow in the presence of mannitol as a sole substrate, despite the fact that this is one of the principal substrates utilised from mucilage (Linley et al., 1981) so that other components in both mucilage and particulate debris are also necessary to promote bacterial growth. The freshly powdered kelp frond may thus provide a complex substrate which allows a considerably greater bacterial growth than the dissolved components alone. It is noteworthy that Haines and Hanson (1979) have obtained a conversion efficiency of plant material into microbial biomass on an ash-free basis of $19.4 \%$ for Salicornia, $55.6 \%$ for Juncus and $64.3 \%$ for Spartina in nitrogen-enriched cultures (see also Fallon and Pfaender, 1976) which are comparable with the carbon:carbon conversion value of $33 \%$ obtained for the initial phase of degradation of kelp debris.

Although the bacterial biomass is controlled by the type and abundance of flagellates and ciliates in culture media (Linley et al., 1981), it will be noted from Figure 2 that flagellates did not appear in abundance until after Day 10. The values for conversion efficiency of only $11 \%$ between Days 6 and 10, compared with $29.4 \%$ which has been obtained for mucilage from Laminaria pallida incubated in seawater (Lucas et al., 1981) and $66 \%$ for the initial leaching phase of the particulate material, may thus genuinely reflect the refractory component of the particulate debris comprising mainly alginates (Newell and Lucas, in press) which remain after more soluble compounds have been removed by leaching. By this time the bacteria were noted to be mainly attached forms which were evidently using the particulate component as a substrate. Lucas et al. (1981) have shown that the time for $50 \%$ utilisation of mannitol in incubation media containing mucilage from L. pallida is $48 \mathrm{~h}$ at $10^{\circ} \mathrm{C}$, and for sugars and alginates is approximately $144 \mathrm{~h}$. Table 4 reveals that $50 \%$ of the particulate component is utilised in $240 \mathrm{~h}$ at this temperature. Differences in the conversion efficiency of soluble components and particulate debris from L. pallida are thus also reflected in the time taken for utilisation by microheterotrophs under culture conditions.
The bacterial biomass which is likely to be supported by particulate debris from a kelp bed may be estimated from data for the production of particulate matter by kelp (Dieckmann, 1978; see also Newell et al., 1980). These values may then be summed with those supported by mucilage alone (Lucas et al., 1981) to provide some indication of the annual microheterotroph biomass which could be supported in the coastal waters adjacent to a kelp bed.

The values for carbon production by Laminaria palIida and Ecklonia maxima, the two principal components of kelp beds off the Cape Peninsula, were summarised from various sources by Newell et al. (1980). An average value of $1172.2 \mathrm{~g} \mathrm{C} \mathrm{m}^{-2} \mathrm{y}^{-1}$ would yield some $938 \mathrm{~g} \mathrm{C} \mathrm{m}^{-2} \mathrm{Y}^{-1}$ as particulate matter if up to $80 \%$ of the carbon is released as particulate debris (Johnston et al., 1977). It is likely that the conversion efficiency of $11 \%$ which we have calculated for the particulate debris from L. pallida applies also to that from E. maxima, and that the annual particulate matter released from the kelp bed of $937.7 \mathrm{~g} \mathrm{C} \mathrm{m}^{-2}$ would thus be capable of supporting $103.15 \mathrm{~g}$ bacterial biomass

Table 7. Carbon production by kelp and total microbial biomass supported by combined production of Laminaria pallida and Ecklonia maxima in a typical kelp bed of 700 ha. Data assembled from sources cited

\section{Source}

Average carbon production for mixed kelp beds (Newell et al., 1980, from various sources)

$$
1172.2 \mathrm{~g} \mathrm{~m}^{-2} \mathrm{y}^{-1}
$$

Particulate carbon production at $80 \%$ of total (Johnston et al., 1977)

Bacterial biomass (conversion efficiency of $11 \%$ )

Area of kelp bed

Total carbon production from kelp bed

$937.7 \mathrm{~g} \mathrm{~m}^{-2} \mathrm{y}^{-1}$

$103.15 \mathrm{~g} \mathrm{~m}^{-2}$ of kelp $\mathrm{y}^{-1}$

$700 \times 10^{4} \mathrm{~m}^{2}$

$820.5 \times 10^{4} \mathrm{~kg}$

Total particulate carbon production from kelp bed

$656.4 \times 10^{4} \mathrm{~kg}$

Annual bacterial biomass supported by particulate carbon production of kelp bed

$72.20 \times 10^{4} \mathrm{~kg}$

Annual bacterial biomasssupported by mucilage production of kelp bed (Lucas et al, 1981)

$$
29.9 \times 10^{4} \mathrm{~kg}
$$

Total bacterial biomass from annual kelp bed carbon production $102.10 \times 10^{4} \mathrm{~kg}$ 
$m^{-2}$ of kelp bed. The area of a typical kelp bed at Kommetjie, on the west coast of the Cape Peninsula, is $700 \times 10^{4} \mathrm{~m}^{2}$ (Newell et al., 1980), so that annual particulate production is of the order of $656 \times 10^{4} \mathrm{~kg}$ and would be capable of supporting an annual dry biomass of $72.2 \times 10^{4} \mathrm{~kg}$ bacteria as shown in Table 7 . Lucas et al. (1980) estimated that the smaller amounts of carbon released as dissolved components in mucilage from such a kelp bed is converted with an efficiency of up to $29 \%$ in the summer but only $12 \%$ in the winter (annual average: $21 \%$ ) and could support an annual bacterial biomass of approximately $30 \times 10^{4}$ $\mathrm{kg}$. The annual production by the kelp bed is thus capable of supporting at least $102.1 \times 10^{4} \mathrm{~kg}$ dry mass bacteria in adjacent shallow coastal waters, and this figure may be considerably higher if we take into account the higher conversion efficiency $(66 \%)$ of soluble components retained within the kelp debris during fragmentation.

The overall energetics of the kelp bed may therefore be summarised as follows. As much as $80 \%$ of the primary carbon production may be released as particulate matter into the water column (Johnston et al., 1977; Hatcher et al., 1977) and is converted to bacterial biomass with an efficiency of approximately $11 \%$. The remaining $20 \%$ of primary carbon production by the kelp is released as a dissolved component which is converted more rapidly than particulate components and with an efficiency of $21 \%$ but which may reach an efficiency of approximately $30 \%$ during summer (Lucas et al., 1981). An undetermined proportion of this soluble material may be retained in the particles during fragmentation and the carbon subsequently converted into bacterial biomass with an efficiency of as much as $66 \%$. Overall conversion from carbon production by the kelp through particulate organic matter to bacteria is thus achieved with an efficiency of $11 \% \times$ $0.8=8.8 \%$, whilst that through the dissolved fraction is at least $21 \% \times 0.2=4.2 \%$ and may be considerably higher during summer. This yields an overall annual conversion from primary production by kelp into bacterial biomass of $13 \%$ through the first step of the decomposer food web based on kelp.

Because of the high conversion efficiency of the relatively small proportion of mucilage into bacterial biomass, the contribution of dissolved organic components released during fragmentation is as much as $50 \%$ of that of particulate debris. Nevertheless, the large quantities of particulate matter and their slow rate of degradation probably allows export of bacterial aggregates to peripheral habitats adjacent to the kelp bed, whilst the free-living bacteria which characterise the inshore waters (Linley and Field, 1981), and which probably utilise mainly the dissolved components of mucilage, may be restricted to the immediate vicinity of the kelp bed.

Acknowledgements. We would like to express our gratitude in particular to Miss Anne Linley of the Zoology Department, University of Cape Town, for technical assistance and advice with the electron microscopy work. This was carried out in the E.M. unit of the University of Cape Town, run by Dr. D. Crawford to whom we are also grateful. The work was funded principally from SANCOR through the kelp bed project of The University of Cape Town and subsequently completed during tenure of a Royal Society Senior Research Fellowship by Dr. R. C. Newell at IMER, Plymouth. The receipt of a CSIR postgraduate bursary by Miss $V$ Stuart is gratefully acknowledged.

\section{LITERATURE CITED}

Calkins, G. N., Summers, F. M. (eds) (1941). Protozoa in biological research, Columbia University Press, New York

Chan, E. C. S., McManus, E. A. (1969). Distribution, characteristics and nutrition of marine micro-organisms from the algae Polysiphonia lanosa and Ascophyllum nodosum. Can J. Microbiol. 15: 409-420

Dieckmann, G. S. (1978). Aspects of growth and production of Laminaria pallida (Grev.) J. Ag. off the Cape Peninsula. M. Sc. thesis, Dept. Botany, University of Cape Town

Doetsch, R. N., Cook, I M. (1973). Introduction to bacteria and their eco-biology, Medical and Technical Publishing Company, Lancaster, England

Dubois, M., Gilles, K. A., Hamilton, J. K., Rebers, P. A., Smith, F. (1956). Colorimetric method for determination of sugars and related substances. Analyt. Chem. 28: 350-356

Fallon, R. D., Pfaender, F. K. (1976). Carbon metabolism in model microbial systems from a temperate soft marsh. Appl. environ. Microbiol. 31: 959-968

Fenchel, T. (1970). Studies on the decomposition of organic detritus derived from the turtle grass Thalassia testudinum. Limnol. Oceanogr. 15: 14-20

Fenchel, T. (1972). Aspects of the decomposer food chains in marine benthos. Verh. dt. zool. Ges. 65 (Sonderheft): $14-22$

Field, J. G., Griffiths, C. L., Linley, E. A. S., Carter, R. A., Zoutendyk, P. (1980). Upwelling in a nearshore marine ecosystem and its biological implications. Estuar coast. mar. Sci. 11: 133-150

Haines, E. B., Hanson, R. B. (1979). Experimental degradation of detritus made from the salt marsh plants Spartina alterniflora Loisel., Salicornia virginica L., and Juncus roemerianus Scheele J. exp. mar. Biol. Ecol. 40: 27-40

Harrison, P. G., Mann, K. H. (1975 a). Chemical changes during the seasonal cycle of growth and decay in eelgrass (Zostera marina) on the Atlantic coast of Canada. J. Fish. Res. Bd Can. 32: 615-621

Harrison, P. G., Mann, K. H. (1975 b). Detritus formation from eelgrass (Zostera marina L.): the relative effects of fragmentation, leaching and decay. Limnol. Ocenogr. 20 (6): 924-934

Hatcher, B. G., Chapman, A. R. O., Mann, K. H. (1977). An annual carbon budget for the kelp Laminaria longicruris. Mar. Biol. 44: 85-96

Hobbie, J. E., Daley, R. T., Jasper, S. (1977). Use of Nuclepore filters for counting bacteria by fluorescence microscopy. Appl. environ. Microbiol. 33 (5): 1225-1228

Johnston, C. S., Jones, R. G., Hunt, R. D. (1977). A seasonal 
carbon budget for a laminarian population in a Scottish sea loch. Helgoländer wiss. Meeresunters. 30: 527-545

Knauer, G. A., Ayres, A. V. (1977). Changes in carbon, nitrogen, adenosine triphosphate, and chlorophyll a in decomposing Thalassia testudinum. Limnol. Oceanogr. 22 (3): $408-414$

Laycock, R. A. (1974). The detrital food chain based on seaweeds. I. Bacteria associated with the surface of Laminaria fronds. Mar. Biol. 25: 223-231

Linley, E. A. S., Field, J. G. (1981). The nature and ecological significance of bacterial aggregation in a nearshore upwelling system. Estuar coast, mar. Sci., in press

Linley, E. A. S., NeweII, R. C., Bosma, S. (1981). Heterotrophic utilisation of mucilage released during fragmentation of kelp (Ecklonia maxima and Laminaria pallida). I. Development of microbial communities associated with the degradation of kelp mucilage. Mar. Ecol. Prog. Ser. 4: $31-41$

Lucas, M. I., Newell, R. C., Velimiroy, B. (1981). Heterotrophic utilisation of mucilage released during fragmentation of kelp (Ecklonia maxima and Laminaria pallida). II. Differential utilisation of dissolved organic components from kelp mucilage. Mar. Ecol. Prog. Ser. 4: 43-55

Luria, S. E. (1960). The bacterial protoplasm: composition and organisation. In: Gunsalus, I. C.. Stanier, R. Y. (eds) The bacteria, Vol. 1. Academic Press, New York, pp. 1-34

Mann, K. H. (1973). Seaweeds: Their productivity and strategy for growth. Science, N.Y 182: 975-981

Marshall, M. (1970). Food transfer through the lower trophic levels of the benthic environment. In: Steele, J. H. (ed.) Marine food chains. Oliver and Boyd, Edinburgh, pp. $52-56$

Mazure, H. G. F., Field, J. G. (1980). Density and ecological importance of bacteria on kelp fronds in an upwelling region. J. exp. mar. Biol. Ecol. 43: 173-182

Newell, R. C. (1965). The role of detritus in the nutrition of two marine deposit feeders, the prosobranch Hydrobia ulvae and the bivalve Macoma balthica. Proc. Zool. Soc. Lond. 144: $25-45$

Newell, R. C. (1979). Biology of intertidal animals, 3rd ed., Marine Ecological Surveys, Faversham, Kent

Newell, R. C., Lucas, M. I. (1981). The quantitative significance of dissolved and particulate organic matter released during fragmentation of kelp in coastal waters. Proc. 15th European Marine Biol. Symp. Kiel. Kieler Meeresforsch.. in press

Newell, R. C., Lucas, M. I., Velimirov, B., Seiderer, L. J (1980). Quantitative significance of dissolved organic losses following fragmentation of kelp (Ecklonia maxima and Laminaria pallida). Mar. Ecol. Prog. Ser. 2: 45-59

Odum, P., De la Cruz, A. A. (1967). Particulate organic detritus in a Georgia salt marsh - estuarine ecosystem. pp. 383-388 In: Lauff, G. H. (ed.) Estuaries, American Association for the Advancement of Science, Washington D.C.

Penhale, P. A., Smith, W. O. (1977). Extraction of dissolved organic carbon by eelgrass (Zostera marina) and its epiphytes. Limnol. Oceanogr. 22: 3: 400-407

Strickland, J. D. H., Parsons, T. R. (1972). A practical handbook of seawater analysis, 2nd ed. Fisheries Research Board of Canada. Bulletin 167

Teal, J. M. (1962). Energy flow in the salt marsh ecosystem of Georgia. Ecology 43: 614-624

Tenore, K. R., (1975). Detrital utilisation by the polychaete Capitella capitata. J. mar Res. 33: 3: 261-274

Wheeler, J. R. (1976). Fractionation by molecular weight of organic substances in Georgia coastal water. Limnol. Ocenogr 21: 847-852

Williams, R. B., Murdoch, M. B. (1969). The potential importance of Spartina alterniflora in conveying zinc, manganese and iron into estuarine food chains. In: National Technical Information Centre, Washington D.C., pp. 431-439

Woodwell, G. M., Whitney, D. E., Hall, C. A. S., Houghton, R. A. (1977). The Flax Pond ecosystem study: Exchanges of carbon in water between a saltmarsh and Long Island Sound. Limnol. Oceanogr. 22: 5: 833-838 